The International Journal of Indian Psychology

ISSN 2348-5396 (e) | ISSN: 2349-3429 (p)

Volume 3, Issue 4, No. 66, DIP: 18.01.157/20160304

ISBN: 978-1-365-39396-9

http://www.ijip.in | July-September, 2016

\title{
Level of Aspiration among Secondary School Teachers
}

\author{
Ms. Manisha ${ }^{1 *}$
}

\section{ABSTRACT}

The present investigation was to find the level of aspiration among secondary school teachers. Survey method of investigation was employed. The findings of the study showed that there is a significant difference between male and female secondary school teachers in relation to their level of aspiration. Significant difference was obtained between rural and urban secondary school teachers in relation to their level of aspiration. Significant difference was also found between govt. and non-govt secondary school teachers in relation to their level of aspiration.

\section{Keywords: Level of Aspiration and Secondary School teachers}

Every person while doing any task, especially one in which he/she has a high interest, becomes ego involved in it. Therefore, doing the task successfully give the individual pleasure. Successful or failure in a task or the corresponding happiness and sadness, depends on his determination of level of aspiration. Srivastava (2009). Atkinson (1957) connected the achievement approach with Lewin's theory of aspiration level (Lewin, Dembo, festinger \& sears, 1944) and explained the role of aspiration in the achievement of targets. Success motivated individual tend to set moderate or high levels of aspiration, whereas failure motivated individuals tend to set aspiration levels either very high or low (Heckhausen, 1980).

Aspirations have been shown to be a strong predictor of outcomes, in other words achievements. The aspiration level of teachers has a great impact on the outcomes of education system. If a teacher is of high aspiration, the results will definitely be high and low with low level of aspiration. Therefore, there arises a need to study the level of aspirations among secondary school teachers to study the expected outcomes in education system.

\section{METHODOLOGY}

The present study is a survey type in nature. Here the data has been collected personally from the teachers. The method applied is of descriptive type. Purposive sampling method was used to select the schools.

\footnotetext{
${ }^{1}$ Assist. Prof. S.S.G.D.C.O.E, Panchkula, Haryana, India

*Responding Author

(C) 2016, Manisha; licensee IJIP. This is an Open Access Research distributed under the terms of the Creative Commons Attribution License (http://creativecommons.org/licenses/by/2.0), which permits unrestricted use, distribution, and reproduction in any Medium, provided the original work is properly cited.
} 


\section{Sample}

A sample of 200 secondary school teachers was selected from 10 government and nongovernment schools of Panchkula district of Haryana state.

\section{Objectives}

1. To study the level of Aspiration among male and female secondary school teachers.

2. To study the level of Aspiration among govt. and non- govt. secondary school teachers.

3. To study the level of Aspiration among rural and urban secondary school teachers.

\section{Hypotheses}

1. There exists a significant difference between male and female secondary school teachers in relation to their level of Aspiration.

2. There exists a significant difference between govt. and non-govt. secondary school teachers in relation to their level of Aspiration.

3. There exists a significant difference between rural and urban secondary school teachers in relation to their level of Aspiration.

\section{Tool Used}

'Level of Aspiration Test' by Shrivastva (2009) was used for the collection of the data.

\section{RESULTS AND DISCUSSIONS}

Table 1: showing difference between male and female secondary school teachers in relation to their level of Aspiration.

\begin{tabular}{|l|l|l|l|l|l|}
\hline Sr. No. & N & Mean & S.D. & SEM & t- value \\
\hline 1 & 100 (males) & 48 & 10 & 1.00 & 13.41 \\
\cline { 1 - 5 } 2 & 100 (females) & 26 & 13 & 1.30 & \\
\hline
\end{tabular}

It is observed from the table that the t- value is 13.41 which is not significant. Thus it shows that males and females show significant difference in relation to their level of Aspiration. Therefore, hypothesis no. 1 i.e. There exists a significant difference between male and female secondary school teachers in relation to their level of Aspiration, is accepted.

Table 2: showing difference between govt. and non-govt. secondary school teachers in relation to their level of Aspiration.

\begin{tabular}{|l|l|l|l|l|l|}
\hline Sr. No. & N & Mean & S.D. & SEM & t- value \\
\hline 1 & 100 (govt.) & 47 & 7 & 0.70 & 16.66 \\
\hline 2 & 100 (non-govt.) & 28 & 9 & 0.90 & \\
\hline
\end{tabular}

It is observed from the table that the t- value is 16.66 which is significant. Thus it shows that govt. and non- govt. secondary school teacher show significant difference in relation to their level of Aspiration. Therefore, hypothesis no. 2 i.e. There exists a significant difference between govt. and non-govt. secondary school teachers in relation to their level of Aspiration, is accepted.

(C) The International Journal of Indian Psychology, ISSN 2348-5396 (e)| ISSN: 2349-3429 (p) | 41 
Level of Aspiration among Secondary School Teachers

Table 3: showing difference between rural and urban secondary school teachers in relation to their level of Aspiration

\begin{tabular}{|l|l|l|l|l|l|}
\hline Sr. No. & N & Mean & S.D. & SEM & t- value \\
\hline 1 & 100 (rural & 48 & 9 & 0.90 & 13.33 \\
\hline 2 & 100 (urban) & 28 & 12 & 1.20 & \\
\hline
\end{tabular}

It is observed from the table that the t- value is 13.33 which is significant. Thus it shows that rural and urban teachers show significant difference in relation to their level of Aspiration. Therefore, hypothesis no. 3 i.e There exists a significant difference between rural and urban secondary school teachers in relation to their level of Aspiration, is accepted.

\section{CONCLUSIONS}

On the basis of the present study the following conclusions have been drawn:

1. There exists a significant difference between male and female secondary school teachers in relation to their level of Aspiration.

2. There exists a significant difference between govt. and non-govt. secondary school teachers in relation to their level of Aspiration.

3. There exists a significant difference between rural and urban secondary school teachers in relation to their level of Aspiration.

\section{Acknowledgments}

The author appreciates all those who participated in the study and helped to facilitate the research process.

\section{Conflict of Interests}

The author declared no conflict of interests.

\section{REFERENCES}

Atkinson, J.W. (1957). Motivational determinations of risk taking behaviour. Psychological Review, Vol. 64, 359-372.

Bakar, A.R. (2004). Academic Performance, Educational and Vocational Aspirations of Technical Secondary School Students, Pertanika Journal of Science and Humanity, Vol. $12,1,31-43$.

Beena, S. (1995). Determinants of Teaching Effectiveness, The Indian Publications, Ambala Cantt., Haryana, India.

Benjamin,L.T.; Hopkins, N. \& Jack, R. (1990). Book on Psychology, Macmillan Publication co., 866 Third Avenue, new York, p495.

Cattell, R.B. \& Butcher, H. J. (1968). The Prediction of Achievement and Aspiration, Dobss Merrill, New York.

Coleman, A. M. (2001). Dictionary of Psychology. Oxford University Press, New Delhi.

Coleman, J.C. (1973). Psychology and Effective Behaviour. D.B. Taraporevala Sons and Co. Pvt. Ltd, New Delhi.

Goyal, J. C. (1980). A study of the relationship among Attitude, Job Satisfaction, Adjustment and Professional Interest of teacher Educators in India. Butch Third Survey of research in Education, NCERT, New Delhi. 


\section{Level of Aspiration among Secondary School Teachers}

Goyal, M. \& Prakash, J. (2011). Empowering women for high Aspiration, Journal of Multidisciplinary International Research, Vol. 1,5, $42-47$.

Heckhausen, H. (1980). A hand Book on Motivation \& Aspiration, Berlin Press, Heidelberg, New York.

Jerslid, A.T. (1968). Educational Psychology, Prentice Hall of India Pvt. Ltd., New Delhi.

John, G. (1992). Can Achievement Motivation Theory succeed with only one Concept of Success?, International Perspectives on achievement and task Motivation, vol. 4, 169.

Lewin, K. et. al. (1994). Level of Aspiration, Personality \& Behaviour Disorder, Vol. 1, Ronald press, New York.

Nuthana, P.G. (1994). Influence of Self Concept on Aspiration, Karnataka Journal of Agriculture Science, Vol. 22 (5), 135-138.

Nuttal. E. V. (1976). Parent Child Relationship and Aspiration, Journal of Psychology, Vol. 94, 127-133.

Panda, B.N. (1995). Personality and aspirations of Children of Working and Non- Working Women, Indian Journal of Psychometry and Education, vol 26, 2, 91-96.

Patel, M.R. (1996). Aspirations of Pupils and its Impact on Achievement, The Progress of Education, Vol. 31, 74-76.

Sudhir, M.A. (1997). Personality and Aspiration among Secondary School Students, Indian Educational Review, 32, 2, 115.

Sweta, K.M. (2008). Value of secondary school students at Various levels of Aspiration, Achievement and intelligence, Ph.D. Education , Choudhri Charan Singh University, Meerut.

Thakur, P. (2003). Study of Aspiration, Achievement and Study Habits of rural and urban Students, Ph.D. (Education), University of Mumbai.

Verma, S. \& Kumar, R. (1999). A Correlational Study of Aspiration and Achievement in different School Courses, Indian Journal of Psychometry and Education, 30, 53-56.

Wikline, J. \& Shepherd, D (2003), Aspiring \& Achieving Growth: The Moderating Role of Resources \& Opportunities, Journal of Management Studies, Vol. 40, 919-941.

How to cite this article: Manisha (2016), Level of Aspiration among Secondary School Teachers, International Journal of Indian Psychology, Volume 3, Issue 4, No. 66, ISSN 23485396 (e), ISSN: 2349-3429 (p), DIP:18.01.157/20160304, ISBN: 978-1-365-39396-9 